\title{
Nitrogen variable rate in pastures using optical sensors
}

\section{Taxa variável de nitrogênio em pastagens utilizando sensores ópticos}

\author{
Lucas de Paula Corrêdo ${ }^{1 *}$; Francisco de Assis de Carvalho Pinto ${ }^{2}$; Domingos Savio \\ Queiroz ${ }^{3}$; Domingos Sárvio Magalhães Valente ${ }^{4}$; Flora Maria de Melo Villar ${ }^{4}$
}

\begin{abstract}
The use of optical sensors to identify the nutritional needs of agricultural crops has been the subject of several studies using precision agriculture techniques. In this work, we sought to overcome the lack of research evaluating the use of these techniques in the management of nitrogen $(\mathrm{N})$ fertilizer in pastures. We evaluated the methodology of the nitrogen sufficiency index (NSI) in N management at variable rates (VR) using a portable chlorophyll meter. In addition, the use of color vegetation indices generated from a digital camera was evaluated as a low-cost alternative. The work was conducted in four management cycles at different times of year, evaluating the productivity and quality of Brachiaria brizantha $\mathrm{cv}$. Xaraés grass. Three NSIs $(0.85,0.90$ and 0.95$)$ were evaluated, applying complementary doses of $\mathrm{N}$ according to the response of monitored plots using a chlorophyll meter and comparing the productivity and leaf $\mathrm{N}$ content of these treatments to the reference treatment $\left(\mathrm{T}_{\mathrm{REF}}\right)$, which received a single dose of $\mathrm{N}\left(150 \mathrm{~kg} \mathrm{ha}^{-1}\right)$. Together with these treatments, plots without $\mathrm{N}$ application (control) were analyzed, totaling five treatments with six replications in a completely randomized design. The dry mass productivity and $\mathrm{N}$ leaf concentration of the VR treatments were statistically equal to $\mathrm{T}_{\mathrm{REF}}$ in all management cycles $(\mathrm{P}<0.05)$. Most color vegetation indices correlated significantly $(\mathrm{P}<0.05)$ to the chlorophyll readings. The use of NSI methodology in pastures allows the same productivity gains, with significant input savings. In addition, the use of digital cameras presents itself as a viable alternative to monitoring the $\mathrm{N}$ status in pastures.
\end{abstract}

Key words: Precision agriculture. NSI. Vegetation index. Brachiaria brizantha. Xaraés grass.

\section{Resumo}

O uso de sensores óticos para identificação das necessidades nutricionais de culturas agrícolas tem sido objeto de diversas pesquisas empregando técnicas de agricultura de precisão. Nesse trabalho buscou-se suprir a carência de pesquisas avaliando o emprego dessas técnicas no manejo de adubo nitrogenado $(\mathrm{N})$ em pastagens. Avaliamos a metodologia do índice de suficiência de nitrogênio (NSI) no manejo de $\mathrm{N}$ a taxa variada (VR) com o uso de um medidor de clorofila portátil. Além disso, avaliou-se o uso de uma câmera digital como uma alternativa de baixo custo. $\mathrm{O}$ trabalho foi conduzido por quatro ciclos de manejo em diferentes épocas do ano, avaliando a produtividade e qualidade do capim Brachiaria brizantha cv. Xaraés. Foram avaliados três NSIs $(0,85 ; 0,90$ e 0,95$)$, aplicando doses complemantares de $\mathrm{N}$ de acordo com a resposta da planta monitorada com o medidor de clorofila, comparando a produtividade e teor

\footnotetext{
${ }^{1}$ Eng $^{\circ}$ Agrícola, Discente do Curso de Doutorado do Programa de Pós-Graduação em Engenharia de Sistemas Agrícolas, Universidade de São Paulo, ESALQ/USP, Piracicaba, SP, Brasil. E-mail: lucaspcorredo@usp.br

2 Eng $^{\circ}$ Agrícola, Prof. Dr., Programa de Pós-Graduação em Engenharia Agrícola, PPGEA, Universidade Federal de Viçosa, UFV, Viçosa, MG, Brasil. E-mail: facpinto@ufv.br

3 Zootecnista, Pesquisador Dr., Empresa de Pesquisa Agropecuária de Minas Gerais, EPAMIG, Viçosa, MG, Brasil. E-mail: dqueiroz@epamig.br

4 Engos Agrícolas, Profs. Drs., PPGEA, UFV, Viçosa, MG, Brasil. E-mail: valente@ufv.br; flora.villar@ufv.br

* Author for correspondence
} 
de $\mathrm{N}$ foliar desses tratamentos com o tratamento de referência $\left(\mathrm{T}_{\mathrm{REF}}\right)$, que recebeu uma dose única de $\mathrm{N}\left(150 \mathrm{~kg} \mathrm{ha}^{-1}\right)$, conforme recomendações tradicionais. Junto com esses tratamentos foram analisadas parcelas sem aplicação de $\mathrm{N}$ (controle), compondo assim cinco tratamentos, com seis repetições, em delineamento inteiramente casualizado. A produtividade de massa seca e de $\mathrm{N}$ foliar dos tratamentos a VR foi estatisticamente igual a $\mathrm{T}_{\mathrm{REF}} \mathrm{em}$ todos os períodos avaliados $(\mathrm{P}<0,05)$. A maioria dos índices de vegetação aplicados às imagens obtidas com a câmera digital se correlacionaram significativamente $(\mathrm{P}<0,05)$ com as leituras realizadas com o clorofilômetro portátil. O uso da metodologia do NSI em pastagens permite os mesmos ganhos de produtividade, com economias significativas de insumo. E o uso de câmera digital apresenta-se como uma alternativa viável ao monitoramento do status de $\mathrm{N}$ em pastagens.

Palavras-chave: Agricultura de precisão. NSI. Índice de vegetação. Brachiaria brizantha. Xaraés.

\section{Introduction}

Brazil has one of the largest cattle herds in the world, with 171.9 million head of cattle, and a pasture area equivalent to 158.6 million hectares. Of these, 11.8 million hectares are in unproductive conditions (IBGE, 2017), representing a challenge to the development of the activity, regarding the recovery and pastures management.

Inadequate pasture management in Brazil, leading to abandonment of degraded areas, is an object of international concern. Among the commitments made by Brazil at COP 21 (Conference of the Parties) is the commitment to recover 15 million hectares of degraded pasture. This and other actions are aimed at meeting the global goal of reducing greenhouse gas emissions by $43 \%$ by 2030 (ONU, 2015).

Pastures are the main source of nutrition for cattle, and are the most practical and least costly system of animal nutrition (BERNARDI et al., 2016; CAMARGO et al., 2002). They are fundamental in the practice of extensive cattle raising, the predominant production system in the country. And when well-managed, mass available in the dry season may be appropriate to cattle kept in tropical grass pastures, for example (SILVA et al., 2017).

Fertilizer application is one of the most important processes in the determination of yield and quality of forage (BERNARDI et al., 2016). Among the macronutrients required for plant development, nitrogen $(\mathrm{N})$ is of fundamental importance.
Insufficient supply of $\mathrm{N}$ for crops generally leads to reduced photosynthetic capacity due to lower synthesis of chlorophyll and consequently reduces the production of biomass and crude protein (BASSO et al., 2016; WANG et al., 2014; MUTANGA et al., 2004), reducing the quality and efficiency of agricultural activity. However, excessive application of nitrogen fertilizers can lead to environmental problems, such as groundwater contamination and atmospheric pollution (BASSO et al., 2016; GRACE et al., 2011), in addition to causing economic losses and decreased application efficiency.

The identification of the variability of the nutritional needs of the plants in the field is best for the efficient application of nitrogen fertilizers, accounting the variability between organisms and the biogeochemical processes to which the $\mathrm{N}$ in the soil is subject. Knowing the spatial variability of this attribute, it is possible to apply precision agriculture techniques, which allow increased productivity, reducing the use of inputs and environmental impact through site-specific management (HE et al., 2016; SABERIOON et al., 2014; BASSO et al., 2013; PERALTA; COSTA, 2013; ROBERTSON et al., 2012). However, the benefits reached using precision management techniques depend on the accuracy of the variability identification (BASSO et al., 2016). In addition, traditional methods of identifying plant attributes in large areas require detailed samplings and expensive laboratory procedures (MUTANGA et al., 2004). 
The spectral reflectance of leaves or the canopy has a high correlation with the foliar $\mathrm{N}$ status of agricultural crops (LI et al., 2014) due to its role in the formation of chlorophyll molecules. Remote sensing of chlorophyll or foliar $\mathrm{N}$ content can provide information on the spatial variability of plant nutrient availability, constituting a low-cost alternative to conventional analyses (BASSO et al., 2016; HUNT JR. et al., 2013; GITELSON et al., 2005).

The American Potash and Phosphate Institute (PPI) published a methodology for $\mathrm{N}$ prescription at variable rate by comparing the chlorophyll content of a reference plot to the chlorophyll content of the field that would receive nitrogen, using an SPAD-502 device. In the reference plot, with small dimensions and located near the field to be treated, a high dose of $\mathrm{N}$ is applied. This comparison is performed by calculating a Nitrogen Sufficiency Index (NSI) (FRANCIS; PIEKIELEK, 1999).

This methodology was initially proposed for grain crops (corn and wheat), but due to its practicality and low cost, it can also be presented as a viable alternative to pasture management in Brazil. Villar et al. (2015) used this methodology in crops of Brachiaria decumbens, obtaining satisfactory results in terms of productivity and economy of input. There is a predominance of grasses of the genus Brachiaria, representing approximately $80 \%$ of the total pasture cultivated in Brazil (CASTRO et al., 2013). There is a great variation of cultivars of these forages, some of which, although present morphological and structural differences, in general presenting good nutritive value and good leaf/ stem ratio (FONTES et al., 2014). Among these, Brachiaria brizantha cv. Xaraés stands out for its high nutritional value, greater forage production, rapid regrowth after grazing, moderate resistance to grasshopper, greater support capacity during the rainy season, and higher annual productivity in low natural soil fertility compared to similar varieties (VALLE et al., 2004).
For the acquisition of data in extensive areas, such as pasture areas destined for Brazilian herds, the use of SPAD, although effective, may present some limitation as to the representativeness of samplings. Several works using different crops were performed to study the use of digital domestic cameras as remote sensing tools, replacing the SPAD in the mapping of N status (COSTA et al., 2015; SABERIOON et al., 2014, JINWEN, 2014; WANG et al., 2014). However, there are neither works using conventional cameras to identify $\mathrm{N}$ status in pastures using the NSI methodology for application of nitrogen fertilizer at variable rates.

The information, based on spectral bands of red and green recorded with conventional cameras, is robust enough to provide information about $\mathrm{N}$ status in plants, even using relatively simple optics of this type of camera and automatic white balance. This information is comparable to dedicated instruments using infrared and red bands (LI et al., 2010). Gitelson et al. (2002) suggest that the intensity of reflectance in the green and red bands could be used as an alternative to red and infrared bands to measure some plant properties.

Given the importance of the application of $\mathrm{N}$ in pastures to provide a quality feed for ruminants and the scarcity of scientific studies addressing the application of precision agriculture techniques to the management of forage plants, this work has the following objectives: a) to evaluate the use of a portable chlorophyll meter using different NSIs for a nitrogen fertilization recommendation at a varied rate in Brachiaria brizantha cv. Xaraés; b) to evaluate the application of $\mathrm{N}$ at a variable rate in forage yield; c) to evaluate different vegetation indices applied to the RGB bands in the recommendation of nitrogen fertilization at a variable rate from images obtained with a conventional camera; and d) to evaluate the possibility of using this camera to replace the SPAD in the evaluation of $\mathrm{N}$ status in Xaraés pastures. 


\section{Materials and Methods}

\section{Experimental area}

The experiment was implemented in the farm of EPAMIG (Agricultural Research Company of Minas Gerais State), Leopoldina City, Brazil, in a field established with Brachiaria brizantha cv. Xaraés, latitude $21^{\circ} 28^{\prime} 22$ ' (S) and longitude 42 43 ' 18 “ (W) and an altitude of approximately $187 \mathrm{~m}$. The soil of the experimental area is classified as RedYellow Alfisol, terrace phase, with a loamy texture.

\section{Characterization and preparation of the experimental area}

Initially, soil sampling for fertility correction was performed on March 14, 2016. The samples were collected in the 0 to $20 \mathrm{~cm}$ layer at random points. The similarity between the chemical analysis of the samples allowed the experiment to be conducted in a completely randomized design.

Between March 15 and 20, the pasture was lowered by grazing, followed by a standardization cut with a tractor-cutter five centimeters from the soil, and removal of excess cut plants from the parcels.

Fertility correction was performed according to the recommendation of the 5th approximation (RIBEIRO et al., 1999), except for nitrogen. On March 21, liming was performed to correct soil acidity, with a dose of $1.3 \mathrm{t} \mathrm{ha}^{-1}(\mathrm{PRNT}=76 \%)$ applied at the beginning of the experiment. In addition, each plot received doses of $500 \mathrm{~kg} \mathrm{ha}^{-1}$ of simple superphosphate and $100 \mathrm{~kg} \mathrm{ha}^{-1}$ of potassium chloride.

The methodology, originally applied for corn and wheat by Francis and Piekielek (1999), determines the complementary doses of $\mathrm{N}$ for these crops, when the calculated NSI is less than 0.95 . The NSI can vary between 0.71 and 0.99 , being characteristic of each crop and even different varieties (COSTA et al., 2015; SAMBORSKI et al., 2009). Costa et al. (2015) found a critical NSI of 0.85 , for which there was no response of the Xaraés pastures in increase of productivity with additional applications of nitrogen. Thus, in present study the treatments were organized as follows:

$\mathrm{T}_{0}$ : control plot, without application of nitrogen fertilizer;

$\mathrm{T}_{\mathrm{REF}}$ : reference plot, with application of $150 \mathrm{~kg}$ $\mathrm{ha}^{-1}$ of nitrogen fertilizer in a single dose of urea;

$\mathrm{T}_{85}$ : variable rate plot with fertilization at a variable rate, using thresholding NSI equal to 0.85 ;

$\mathrm{T}_{90}$ : variable rate plot with fertilization at a variable rate, using thresholding NSI equal to 0.90 ;

$\mathrm{T}_{95}$ : variable rate plot with fertilization at a variable rate, using thresholding NSI equal to 0.95 .

These were allocated in plots of $4 \mathrm{~m} \mathrm{x} 4 \mathrm{~m}$ spaced $1 \mathrm{~m}$ apart, with six replications totaling 30 experimental plots.

At the beginning, $50 \%\left(75 \mathrm{~kg} \mathrm{ha}^{-1}\right)$ of the single dose of nitrogen fertilizer treatment was applied to each variable rate plot.

As a nitrogen management criterion, the Nitrogen Sufficiency Index (NSI) of the $\mathrm{T}_{85}, \mathrm{~T}_{90}$ and $\mathrm{T}_{95}$ treatments was calculated when the canopy of the reference plots $\left(\mathrm{T}_{\mathrm{REF}}\right)$ intercepted 75\% and $85 \%$ of photosynthetically active radiation. When this was lower than the thresholding NSI, a dose of $\mathrm{N}$ equal to $25 \%$ of the reference portion dose (equivalent to $37.50 \mathrm{~kg} \mathrm{ha}^{-1}$ ) was applied. For practical management reasons, and due to the short crop development cycle, two readings were performed between the first application and harvesting. Therefore, the complementary doses were divided in $25 \%$ of the reference dose, to be applied in the two evaluation moments, according to the culture nutritional needs. At the end of the cycle, the maximum possible of nitrogen applied in the variable rate plots would be equivalent to the reference dose. The doses were always applied at the end of the day to minimize urea volatilization and leaching. 
The NSI calculation was performed according to Equation 1 (FRANCIS; PIEKIELEK,1999):

$$
\mathrm{NSI}=\frac{\mathrm{SM}_{\mathrm{vr}}}{\mathrm{SM}_{\mathrm{r}}}
$$

where:

NSI - nitrogen sufficiency index;

$\mathrm{SM}_{\mathrm{vr}}$ - chlorophyll content on the area to be treated by variable rate application; and

$\mathrm{SM}_{\mathrm{r}}$ - chlorophyll content on the reference plot.

\section{Chlorophyll Content}

SPAD-502 (Minolta Corporation, Japan) has been used in much agricultural crop research to assist in decision-making for the application of nitrogenous fertilizers, including pastures (NETTO et al., 2005; PAGOLA et al., 2009; SABERIOON et al., 2013; VILLAR et al., 2015; WIDJAJA PUTRA et al., 2017). In each plot, 30 readings were performed by measuring different randomly selected, new and completely expanded leaves, with the equipment positioned in the intermediate portion of the leaf. After each measure, a step was taken in randomly directions along the plot, in order to selected leaves on different plant canopy. The average of SPAD 30 readings were used to calculate NSI using Equation 1.

\section{Vegetal development and harvesting}

Plant development was monitored using an AccuPAR LP-80 ceptometer (Decagon) by quantifying the intercepted photosynthetically active radiation (IPAR) by the plant canopy. Every two days, four IPAR measurements were performed within each reference plot at random points. When the reference plot IPAR average was $75 \%$ and $85 \%$, the plants of treatments $\mathrm{T}_{85}, \mathrm{~T}_{90}$ and $\mathrm{T}_{95}$ could receive complementary fertilization (equivalent to $37.50 \mathrm{~kg}$ $\mathrm{ha}^{-1}$ ), if necessary, according to the NSI.

The entrance of animals when plants reach $95 \%$ of IPAR is a strategy often used with tropical grasses (EUCLIDES et al., 2014; PEDREIRA et al., 2007). In addition, we monitored solar radiation and rainfall (Figure 1) with data acquired from a meteorological station of INMET (National Meteorological Institute).

Figure 1. Amount of solar radiation and rainfall during experimental period corresponding to four management cycles (MC).

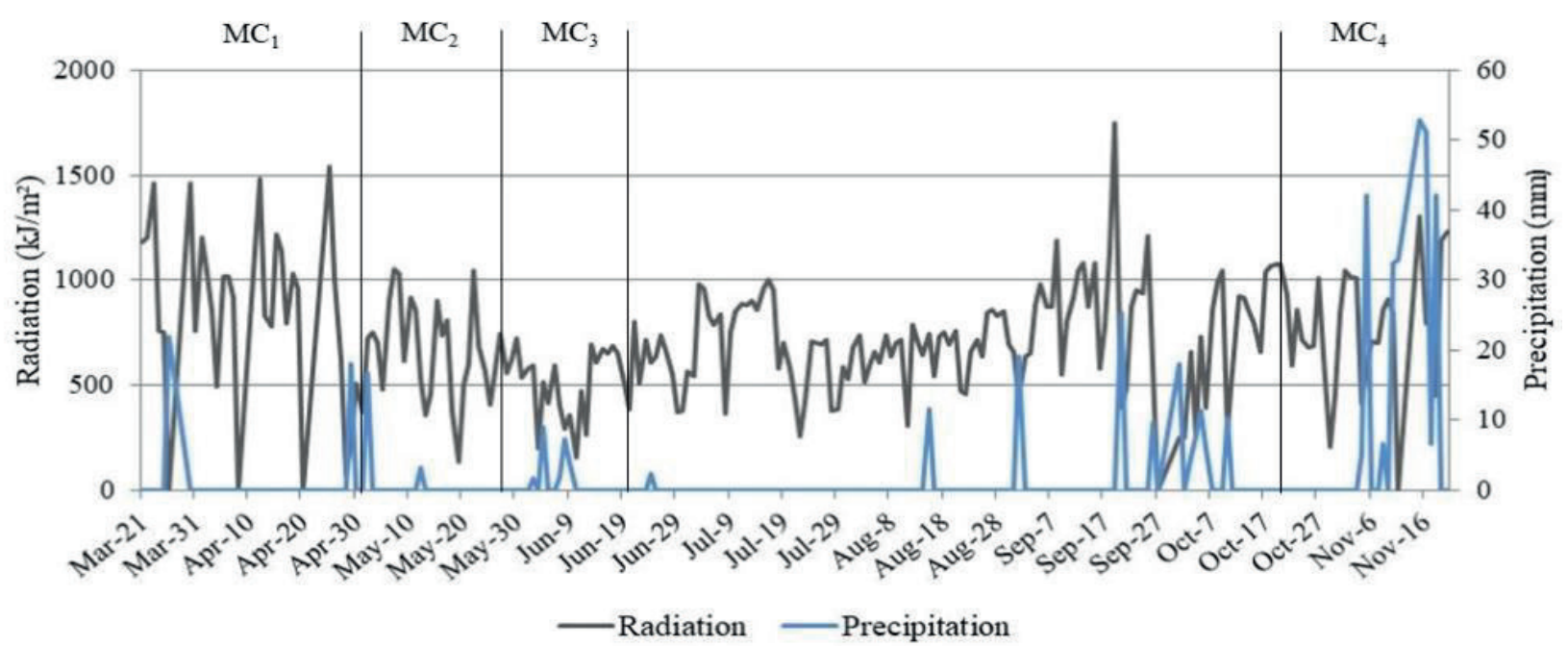


Once the plants of the reference plots reached $95 \%$ of IPAR, a forage sample of $2 \times 2 \mathrm{~m}$ was harvested by cutting at a height of $15 \mathrm{~cm}$, located in the center of each plot, which simulated the forage height recommended to remove animals from the field (PEDREIRA et al., 2009). Sub-samples were dried in laboratory oven, and the dry mass yield for each plot was calculated as proposed by Detmann et al. (2012). Subsequently, the remaining vegetation was made uniform using a costal cutter, following the $15 \mathrm{~cm}$ height of the previously harvested crop, to restart a new management cycle.

\section{Foliar $N$ content, crude protein and $N$ use efficiency}

The oven-dried samples were also used to measure foliar $\mathrm{N}$ content using the Kjeldahl laboratory procedure and foliar crude protein (DETMANN et al., 2012).

Nitrogen use efficiency (NUE) was calculated for each treatment at the end of each management cycle, as the difference between the dry mass produced in $\mathrm{N}$ fertilized plots and the dry mass of the control (without application of N) plots, divided by the $\mathrm{N}$ rate applied (Equation 2).

$$
\mathrm{NUE}=\frac{\mathrm{DM}}{\mathrm{N}_{\mathrm{app}}}
$$

where:

DM - the difference between the yield dry mass of the $\mathrm{N}$ fertilized plot and the yield dry mass of the control plot;

$\mathrm{N}_{\text {app }}$ - the amount of $\mathrm{N}$ applied during the management cycle.

\section{Color vegetation indices}

Images were taken from plots under opensky conditions between 12 and 14 hours using a conventional Sony Cyber-shot DSC-W710 camera attached to a frame at a height of $1.80 \mathrm{~m}$ that was pointed towards the vegetable canopies. The camera was to operate in automatic ISO mode and white balance in daylight mode, and the focus and exposure time functions were set in automatic mode. Three sequential images were taken from the central part of each plot, with a size of 1944 x 2592 pixels, representing an area of approximately 4.12 $\mathrm{m}^{2}$ and a spatial resolution of approximately $1 \mathrm{~mm}$ pixel $^{-1}$.

The images were processed using Matlab software (version R2009b, The MathWorks, USA). Initially, the RGB bands were normalized by Equations 3, 4 and 5.

$$
\begin{aligned}
& r=\frac{R}{R+G+B} \\
& g=\frac{G}{R+G+B} \\
& b=\frac{B}{R+G+B}
\end{aligned}
$$

where $r, g$ and $b$ are the normalized digital values of intensity of the red (R), green $(\mathrm{G})$ and blue (B) bands respectively.

The mean values of digital numbers for each band were used to calculate the vegetation index (VI) (Table 1). Each VI was used as a spectral variable for NSI calculation to evaluate the best index for $\mathrm{N}$ status identification using a conventional digital camera. 
Table 1. Color Vegetation Indices.

\begin{tabular}{|c|c|c|}
\hline Name & Equation & Reference \\
\hline Green Excess & $\mathrm{ExG}=2 \times \mathrm{g}-\mathrm{r}-\mathrm{b}$ & Mao et al. (2003) \\
\hline Red Excess & $\operatorname{ExR}=1.4 \times r-g$ & Mao et al. (2003) \\
\hline Blue Excess & $\mathrm{ExB}=1.4 \times \mathrm{b}-\mathrm{g}$ & Mao et al. (2003) \\
\hline Green minus Red Excess & $E x G R=E x G-E x R$ & Mao et al. (2003) \\
\hline Normalized Different Index & $\mathrm{NDI}=\frac{\mathrm{g}-\mathrm{r}}{\mathrm{g}+\mathrm{r}+0.01}$ & Mao et al. (2003) \\
\hline Green Soil Adjusted Vegetation & $\operatorname{SAVI}_{\text {green }}=\frac{(1+\mathrm{L}) \times(\mathrm{g}-\mathrm{r})}{\mathrm{g}+\mathrm{r}+\mathrm{L}}$ & Li et al. (2010) \\
\hline $\begin{array}{l}\text { RGB Normalized Difference } \\
\text { Vegetation Index }\end{array}$ & $\mathrm{NDVI}_{\mathrm{rgb}}=\frac{\mathrm{g}+\mathrm{b}-\mathrm{r}}{\mathrm{g}+\mathrm{b}+\mathrm{r}}$ & Widjaja Putra et al. (2017) \\
\hline $\begin{array}{l}\text { Green Normalized Difference } \\
\text { Vegetation Index }\end{array}$ & $\mathrm{NDVI}_{\text {green }}=\frac{\mathrm{g}-\mathrm{r}}{\mathrm{g}+\mathrm{r}}$ & Gitelson et al. (2002) \\
\hline Green Minus Red & $\mathrm{GMR}=\mathrm{g}-\mathrm{r}$ & Wang et al. (2013) \\
\hline $\begin{array}{l}\text { Blue-Red Adjusted Vegetation } \\
\text { Index }\end{array}$ & BRAVI $=\frac{n \times(g-r)}{g+r+N}$ & Widjaja Putra et al. (2017) \\
\hline $\begin{array}{l}\text { Green Enhanced Vegetation } \\
\text { Index } 2\end{array}$ & $\mathrm{EVI} 2_{\text {green }}=\frac{2.5 \times(\mathrm{g}-\mathrm{r})}{\mathrm{g}+2.4 \times \mathrm{r}+1}$ & Widjaja Putra et al. (2017) \\
\hline $\begin{array}{l}\text { Green Optimized Soil Adjusted } \\
\text { Vegetation Index }\end{array}$ & OSAVI $_{\text {green }}=\frac{1.5 \times(g-r)}{(g+r)+0.16}$ & Widjaja Putra et al. (2017) \\
\hline
\end{tabular}

$\mathrm{L}=$ crop cover correction factor (assumed here to be 0.5 ) $; \mathrm{n}=$ noise intensity, where noise intensity is equal

\section{Data analyses}

The results of the difference between the dry mass yield of the $\mathrm{N}$ fertilized plot and the dry mass yield of the control plot (DM) and the amount of foliar $\mathrm{N}\left(\mathrm{N}_{\mathrm{DM}}\right)$ were submitted to analysis of variance and Tukey's test for comparison of means at 5\% probability, using the software Rstudio (R CORE TEAM, 2016). In addition, we evaluated the NSI thresholding that offers the best $\mathrm{N}$ use efficiency of $\mathrm{N}$, considering the dry mass productivity and the amount of $\mathrm{N}$ applied.

The images were evaluated for the probability that the NSI, calculated from each vegetation index, indicates the same decision as NSI calculated from the SPAD measurements.

\section{Results and Discussion}

During four management cycles, plant development was monitored using the IPAR. The periods of each cycle, starting with cut and fertilization and continuing through the indirect evaluation of $\mathrm{N}$ status with the chlorophyll meter on two dates, at $75 \%$ and $85 \%$ of IPAR, until harvesting when IPAR was $95 \%$, are shown in Table 2. After the end of the third management cycle $\left(\mathrm{MC}_{3}\right)$, it was decided to conduct the fourth management cycle $\left(\mathrm{MC}_{4}\right)$ in the rainy season, which began in October. Between $\mathrm{MC}_{3}$ and $\mathrm{MC}_{4}$, the plants were cut every 25 days to maintain the field in proper condition. 
Table 2. Beginning and harvesting dates of each management cycle (MC) and SPAD measurement dates according to intercepted photosynthetically active radiation (IPAR) of reference plot plants.

\begin{tabular}{lcccc}
\hline Event & MC $_{1}$ & MC $_{2}$ & $\mathbf{M C}_{3}$ & $\mathbf{M C}_{4}$ \\
\hline Beginning & $03 / 21 / 2016$ & $05 / 04 / 2016$ & $05 / 27 / 2016$ & $10 / 24 / 2016$ \\
$75 \%$ of IPAR & $04 / 14 / 2016$ & $05 / 13 / 2016$ & $06 / 03 / 2016$ & $11 / 08 / 2016$ \\
85\% of IPAR & $04 / 21 / 2016$ & $05 / 18 / 2016$ & $06 / 07 / 2016$ & $11 / 16 / 2016$ \\
95\% of IPAR & $05 / 02 / 2016$ & $05 / 26 / 2016$ & $06 / 20 / 2016$ & $11 / 21 / 2016$ \\
Harvesting & $05 / 03 / 2016$ & $05 / 26 / 2016$ & $06 / 20 / 2016$ & $11 / 21 / 2016$ \\
\hline
\end{tabular}

\section{Yield and forage quality}

During the first management cycle $\left(\mathrm{MC}_{1}\right)$, NSI indicated the need for $\mathrm{N}$ fertilization in all treatments at variable rate (Table 3 ). The maximum applications number of nitrogen complementary doses (Z) would be 12 (six replications and two dates), representing how many times was applied $37.5 \mathrm{~kg} \mathrm{ha}^{-1}$ ( $25 \%$ of the reference portion dose) in each treatment. $\mathrm{N}_{\text {initial }}$ and $\mathrm{N}_{\text {total }}$ describe the averages doses applied at the beginning and end of the cycle to each treatment, respectively. All the variable rate treatments received, in average, less $\mathrm{N}_{\text {total }}$ than the reference plot since the number of complementary $\mathrm{N}$ doses were less than the maximum 12 . There was a predominance of dry climate and high average temperatures, which may have contributed to the volatilization of urea and negatively affected $\mathrm{N}$ uptake after initial fertilization. In addition, because the field had not received fertilizer management before the beginning of the experiment, soil microbiota may have consumed most of the applied nitrogen. Although $\mathrm{T}_{85}$ treatment received the lowest average dose of $\mathrm{N}_{\text {total }}$ until the end of the cycle $\left(81.25 \mathrm{~kg} \mathrm{ha}^{-1}\right)$, its yield dry mass (DM) was statistically similar to other treatments at $5 \%$ of probability by the Tukey test. Likewise, the amount of foliar nitrogen $\left(\mathrm{N}_{\mathrm{DM}}\right)$ was statistically similar in all treatments that received $\mathrm{N}$, at $5 \%$ of probabilities by the Tukey test. Nitrogen use efficiency (NUE) was equivalent for almost all treatments that received $\mathrm{N}$, except for $\mathrm{T}_{85}$, which presented NUE $43 \%$ greater than the reference plot NUE.

The second and third management cycles $\left(\mathrm{MC}_{2}\right.$ and $\mathrm{MC}_{3}$, respectively) tended to show higher-yield dry masses than treatments of $\mathrm{MC}_{1}$, although they received less $\mathrm{N}$ until the end of the cycles $\left(\mathrm{N}_{\text {total }}\right)$ and environmental conditions unfavorable to plant development, with shorter days, lower temperatures and lower rainfall. The $\mathrm{N}_{\text {total }}$ applied in $\mathrm{MC}_{2}$ and $\mathrm{MC}_{3}$ was also inferior to the first management cycle, likely because of the residual effect of fertilization performed on $\mathrm{MC}_{1}$. At the end of these management cycles, $\mathrm{T}_{85}$ and $\mathrm{T}_{90}$ received initial $\mathrm{N}$ doses $\left(75 \mathrm{~kg} \mathrm{ha}^{-1}\right)$ with $\mathrm{MS}$ statistically equal to the other treatments that received nitrogen fertilizer, resulting in a savings of $50 \%$ of the nitrogen fertilizer applied to these treatments. This result led to a better NUE for treatments receiving $\mathrm{N}$ at a variable rate, rather than treatment with a single fixed dose $\left(\mathrm{T}_{\mathrm{REF}}\right)$. For an NSI thresholding of 0.85 $\left(\mathrm{T}_{85}\right)$, NUE was $179 \%$ higher than $\mathrm{T}_{\mathrm{REF}}$ in the $\mathrm{MC}_{3}$, which was the management cycle with worse climatic conditions for plant development.

The fourth management cycle $\left(\mathrm{MC}_{4}\right)$ presented the highest DM relative to the previous three cycles. The average yield dry mass of $\mathrm{MC}_{4}$ was 2164.0 $\mathrm{kg} \mathrm{ha}^{-1}$, while those of $\mathrm{MC}_{1}, \mathrm{MC}_{2}$ and $\mathrm{MC}_{3}$ were $891.4,1135.4$ and $993.2 \mathrm{~kg} \mathrm{ha}^{-1}$, respectively. This can be explained by the climatic conditions of the experiment, favoring the absorption of nutrients by the plants. The period was characterized by the highest temperatures, relative air humidity and rainfall. As in other management cycles, there was no significant difference in DM among the treatments that received nitrogen fertilization in the $\mathrm{MC}_{4}$, even with better environmental conditions. $\mathrm{T}_{85}$ received the initial dose of nitrogen fertilizer during this management cycle, with NUE $142 \%$ higher than the NUE of the fixed $\mathrm{N}$ rate $\left(\mathrm{T}_{\mathrm{REF}}\right)$. 
Table 3. Nitrogen applied at beginning $\left(\mathrm{N}_{\text {initial }}\right)$ and until harvesting $\left(\mathrm{N}_{\text {total }}\right)$, applications number of nitrogen complementary doses $(\mathrm{Z})$, yield dry mass $(\mathrm{DM})$, foliar nitrogen $\left(\mathrm{N}_{\mathrm{F}}\right)$, dry mass foliar nitrogen $\left(\mathrm{N}_{\mathrm{DM}}\right)$, crude protein (CP) and nitrogen use efficiency (NUE) for each management cycle (MC).

\begin{tabular}{|c|c|c|c|c|c|c|c|c|}
\hline Treatment & $\begin{array}{c}\mathrm{N}_{\text {intitial }} \\
\left(\mathrm{kg} \mathrm{hat}^{-1}\right)\end{array}$ & Z & $\begin{array}{c}\mathrm{N}_{\text {total }} \\
\left(\mathrm{kg} \mathrm{ha}^{-1}\right)\end{array}$ & $\begin{array}{c}\mathrm{DM}^{*} \\
\left(\mathrm{~kg} \mathrm{ha}^{-1}\right)\end{array}$ & $\begin{array}{l}\mathrm{N}_{\mathrm{F}} \\
(\%)\end{array}$ & $\begin{array}{c}\mathrm{N}_{\mathrm{DM}}{ }^{*} \\
\left(\mathrm{~kg} \mathrm{ha}^{-1}\right)\end{array}$ & $\begin{array}{l}\mathrm{CP} \\
(\%)\end{array}$ & NUE \\
\hline \multicolumn{9}{|c|}{$\mathrm{MC}_{1}$} \\
\hline $\mathrm{T}_{\mathrm{REF}}$ & 150 & - & 150 & $1156 \mathrm{a}$ & 1.92 & $21.75 \mathrm{a}$ & 11.98 & 4.80 \\
\hline $\mathrm{T}_{95}$ & 75 & 9 & 131.25 & 996 a & 1.87 & $18.25 \mathrm{a}$ & 11.68 & 4.26 \\
\hline $\mathrm{T}_{90}$ & 75 & 4 & 100 & $873 \mathrm{a}$ & 1.71 & $14.98 \mathrm{a}$ & 10.71 & 4.37 \\
\hline $\mathrm{T}_{85}$ & 75 & 1 & 81.25 & 995 a & 1.53 & $15.16 \mathrm{a}$ & 9.58 & 6.88 \\
\hline $\mathrm{T}_{0}$ & 0 & - & 0 & $437 \mathrm{~b}$ & 1.38 & $5.81 \mathrm{~b}$ & 8.62 & - \\
\hline \multicolumn{9}{|c|}{$\mathrm{MC}_{2}$} \\
\hline $\mathrm{T}_{\mathrm{REF}}$ & 150 & - & 150 & $1351 \mathrm{a}$ & 2.37 & $31.84 \mathrm{a}$ & 14.84 & 6.40 \\
\hline $\mathrm{T}_{95}$ & 75 & 1 & 81.25 & $1482 \mathrm{a}$ & 2.32 & $34.03 \mathrm{a}$ & 14.51 & 13.43 \\
\hline $\mathrm{T}_{90}$ & 75 & 0 & 75 & $1305 \mathrm{a}$ & 2.20 & $28.79 \mathrm{a}$ & 13.75 & 12.19 \\
\hline $\mathrm{T}_{85}$ & 75 & 0 & 75 & $1184 \mathrm{a}$ & 2.14 & $25.32 \mathrm{a}$ & 13.38 & 10.58 \\
\hline $\mathrm{T}_{0}$ & 0 & - & 0 & $391 \mathrm{~b}$ & 1.52 & $5.90 \mathrm{~b}$ & 9.52 & - \\
\hline \multicolumn{9}{|c|}{$\mathrm{MC}_{3}$} \\
\hline $\mathrm{T}_{\mathrm{REF}}$ & 150 & - & 150 & $970 \mathrm{a}$ & 2.80 & $27.25 \mathrm{a}$ & 17.52 & 3.47 \\
\hline $\mathrm{T}_{95}$ & 75 & 3 & 93.75 & $1260 \mathrm{a}$ & 2.55 & $32.15 \mathrm{a}$ & 15.94 & 8.64 \\
\hline $\mathrm{T}_{90}$ & 75 & 0 & 75 & $1111 \mathrm{a}$ & 2.48 & $27.71 \mathrm{a}$ & 15.52 & 8.81 \\
\hline $\mathrm{T}_{85}$ & 75 & 0 & 75 & $1175 \mathrm{a}$ & 2.43 & $28.61 \mathrm{a}$ & 15.17 & 9.68 \\
\hline $\mathrm{T}_{0}$ & 0 & - & 0 & $450 \mathrm{~b}$ & 1.59 & $7.19 \mathrm{~b}$ & 9.92 & - \\
\hline \multicolumn{9}{|c|}{$\mathrm{MC}_{4}$} \\
\hline $\mathrm{T}_{\mathrm{REF}}$ & 150 & - & 150 & 2293 a & 2.11 & $48.13 \mathrm{a}$ & 13.21 & 8.96 \\
\hline $\mathrm{T}_{95}$ & 75 & 4 & 100 & 2529 a & 1.88 & $47.02 \mathrm{a}$ & 11.73 & 15.81 \\
\hline $\mathrm{T}_{90}$ & 75 & 3 & 93.75 & $2474 \mathrm{a}$ & 1.73 & $41.29 \mathrm{a}$ & 10.82 & 16.28 \\
\hline $\mathrm{T}_{85}$ & 75 & 0 & 75 & $2576 \mathrm{a}$ & 1.52 & $39.06 \mathrm{a}$ & 9.53 & 21.71 \\
\hline $\mathrm{T}_{0}$ & 0 & - & 0 & $948 \mathrm{~b}$ & 1.14 & $10.63 \mathrm{~b}$ & 7.10 & - \\
\hline
\end{tabular}

$\mathrm{T}_{\text {REF }}$ - reference; $\mathrm{T}_{95}$ - NSI thresholding of $0.95 ; \mathrm{T}_{90}$ - NSI thresholding of $0.90 ; \mathrm{T}_{85}-\mathrm{NSI}$ thresholding of $0.85 ; \mathrm{T}_{0}$ - control; $\mathrm{Z}$ - number of nitrogen complementary applications; " - averages followed by same letter do not differ by $5 \%$ probability by Tukey's test.

Carloto et al. (2011) evaluated the nutritional value, canopy structure, forage intake and animal production in Xaraés pastures, managed at three different heights during the rainy period in Campo Grande, Mato Grosso do Sul state, Brazil. Applying a fixed dose of $100 \mathrm{~kg} \mathrm{ha}^{-1}$ of $\mathrm{N}$ in the form of urea, the yield dry mass average was $6319 \mathrm{~kg} \mathrm{ha}^{-1}$ for plants managed at $30 \mathrm{~cm}$. The DM average obtained was approximately 2.5 -fold higher than the DM in $\mathrm{MC}_{4}$ of the present study. These differences may be due to differences in the harvesting method adopted in each study. The plants were cut close to the ground in the work of Carloto et al. (2011), while in the present work, the plants were managed with cuts at $15-\mathrm{cm}$ high, simulating the height of the animals exiting the field. Thus, a great portion of dry mass produced by the forage remained in the area, composed of roots and plant parts up to 15 $\mathrm{cm}$ high. The management method adopted in the present study increases the speed of regrowth, since it conserves the apical meristem of the plants. 
Pereira et al. (2011) applied 40.0 kg.ha- ${ }^{-1} \mathrm{~N}$ and evaluated the yield dry mass of the cultivars Marandu and Xaraés during all seasons in the arid region of Vale do Jequitinhonha, Minas Gerais State, reaching $972.5 \mathrm{~kg} \mathrm{ha}^{-1}$ for the Xaraés variety during the summer, during which the highest yield occurred, with values near to those obtained in the fourth cycle $\left(\mathrm{MC}_{4}\right)$ of the present study for the treatment without nitrogen fertilizer $\left(\mathrm{T}_{0}\right)$.

The dry mass foliar $\mathrm{N}\left(\mathrm{N}_{\mathrm{DM}}\right)$ in the plant fraction above $15 \mathrm{~cm}$, corresponding to the plant portion consumed by the animals, followed the same trend as dry mass yield (DM) for most management cycles, with no significant difference among the treatments, except for the control plot. Therefore, the NSI threshold used in the variable rate treatments detecting the $\mathrm{N}$ losses may have occurred in the fixed rate treatment, since the variable rate treatments imposed the same amount of $\mathrm{N}_{\mathrm{DM}}$ as the fixed rate treatment but also used less fertilizer.

The percentage of estimated crude protein (CP) ranged from 7.1 to $17.5 \%$ depending on the management cycle and treatment. Carloto et al. (2011) found a CP of approximately $11.2 \%$ for Xaraés forage pastures at $30 \mathrm{~cm}$. Flores et al. (2008) found values from 9.6 to $11.1 \%$ depending on the canopy height. Pereira et al. (2011), working with Xaraés in all seasons, reached up to $12.6 \%$ of PB in the summer.

The $\mathrm{N}$ use efficiency (NUE) of the variable rate treatments were higher than the fixed rate treatment, except in $\mathrm{MC}_{1}$, due to the field history and drastic uniformity cut performed at the beginning of the experiment. $\mathrm{MC}_{1}$ required higher $\mathrm{N}$ for recovery and development of the plants. During $\mathrm{MC}_{1}, \mathrm{~N}$ losses by natural processes, such as volatilization and immobilization by microorganisms, must have occurred more intensely due to the nutritional deficiency of the field.

Lower NSI thresholding to apply N led to lower amounts of fertilizer during a management cycle, since it would require a greater difference between the SPAD readings of the reference plot and the field. Thus, NSI thresholding of 0.85 showed the best option for $\mathrm{N}$ management, with variable rate for Xaraés forage. The use of the methodology proposed by Francis and Piekielek (1999) adapted to pastures of Xaraés, using the SPAD chlorophyll meter, in addition to showing satisfactory results in terms of yield, can mitigate environmental impacts via the application of $\mathrm{N}$ excess, ultimately saving money in input application costs. Therefore, the use of the plant as a biosensor, allowing the effect of the local climate to influence the $\mathrm{N}$ dose, as proposed in the methodology used in the present work, leads to greater efficiency in the recommendation of $\mathrm{N}$ fertilization.

\section{Use of conventional camera in the recommendation} of nitrogen fertilization

The portable chlorophyll meter, although presenting itself as a practical apparatus for monitoring the foliar $\mathrm{N}$ status, has limitations in terms of the sampling area and required number of measurements. Its sampling area is only approximately $6 \mathrm{~mm}^{2}$, and an average of 30 measurements are recommended by the NSI methodology, which, in addition to making the sampling process exhaustive, may compromise the representativeness in a large field with significant spatial variability of attributes. In this context, the use of remote sensing images plays an important role to enable the NSI methodology in large fields, since this would speed information acquisition and increase information representativeness.

Correlations between SPAD readings and color vegetation indices were significant $(\mathrm{P}<0.05)$ for evaluated indices, for all dates and management cycles (Table 4), except ExB, BRAVI and ExGR. The correlation coefficients tended to be lower during $\mathrm{MC}_{4}$ than the other management cycles, possibly due to the variation of illumination, with a greater presence of clouds during $\mathrm{MC}_{4}$. This may influence the vegetation index values since no calibration was used to transform the pixel value into reflectance. 


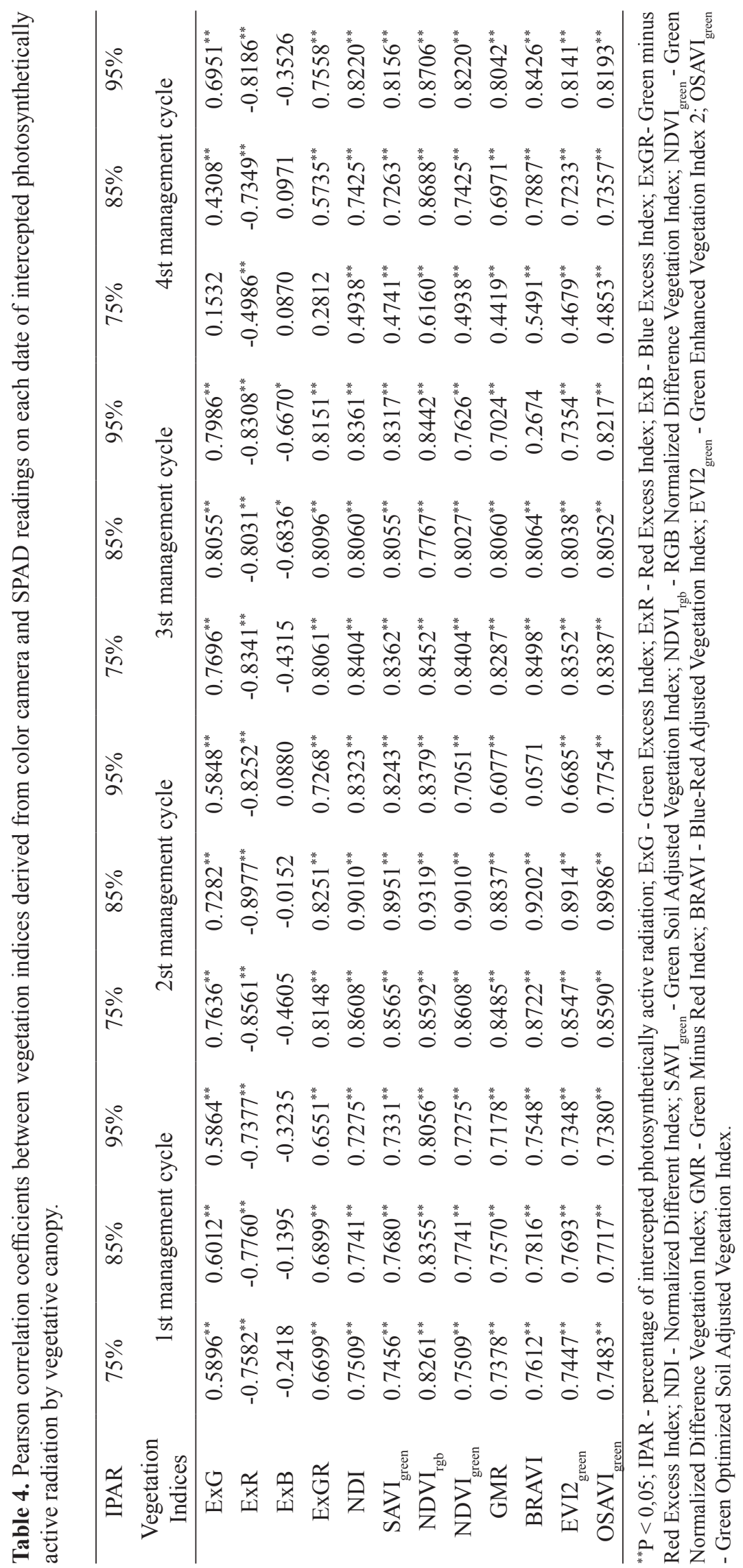


The significant correlation between VIs and performed for the 18 plots that composed the three SPAD indicates the possibility of the use of treatments that received variable rate doses of conventional color cameras to target $\mathrm{N}$ status in nitrogen $\left(\mathrm{T}_{85}, \mathrm{~T}_{90}\right.$ and $\left.\mathrm{T}_{95}\right)$. Figures 2 and 3 show the Xaraés grass canopies. Based on this assumption, number of times decision-making based on SPAD NSI was calculated using each significant VI instead reading coincided with VI value, when IPAR was of SPAD for all studied periods. This analysis was $75 \%$ and $85 \%$, respectively.

Figure 2. Number of times VI-based decision-making coincided with SPAD-based decisions when IPAR was 75\%.

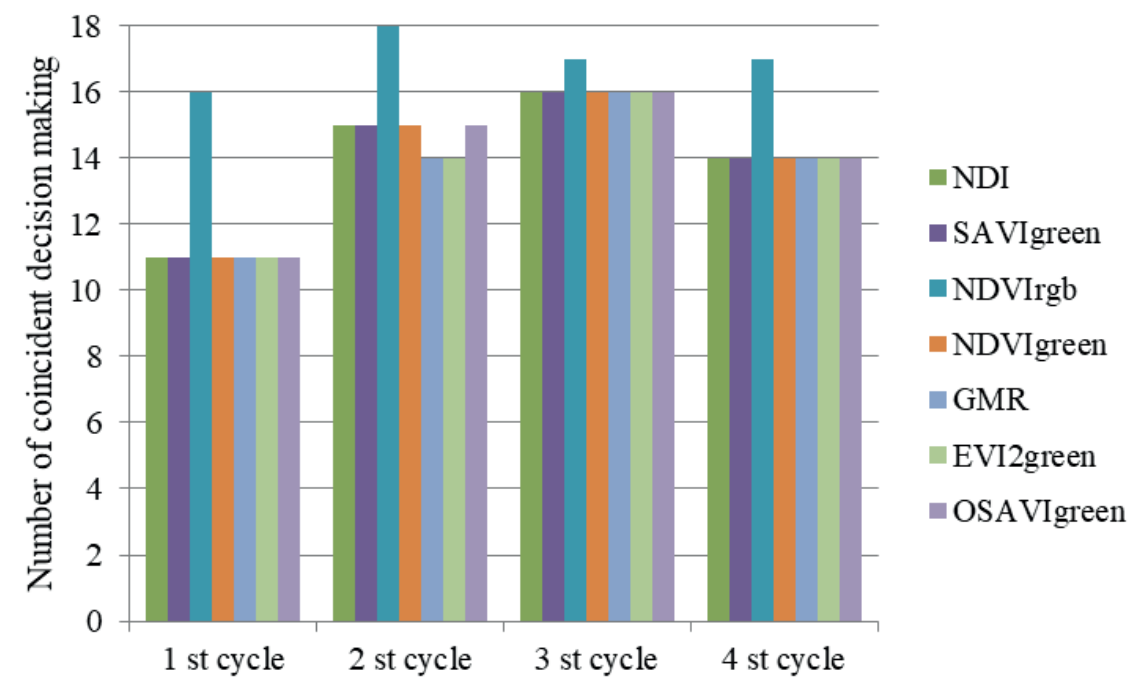

Figure 3. Number of times VI-based decision-making coincided with SPAD-based decisions when IPAR was $85 \%$.

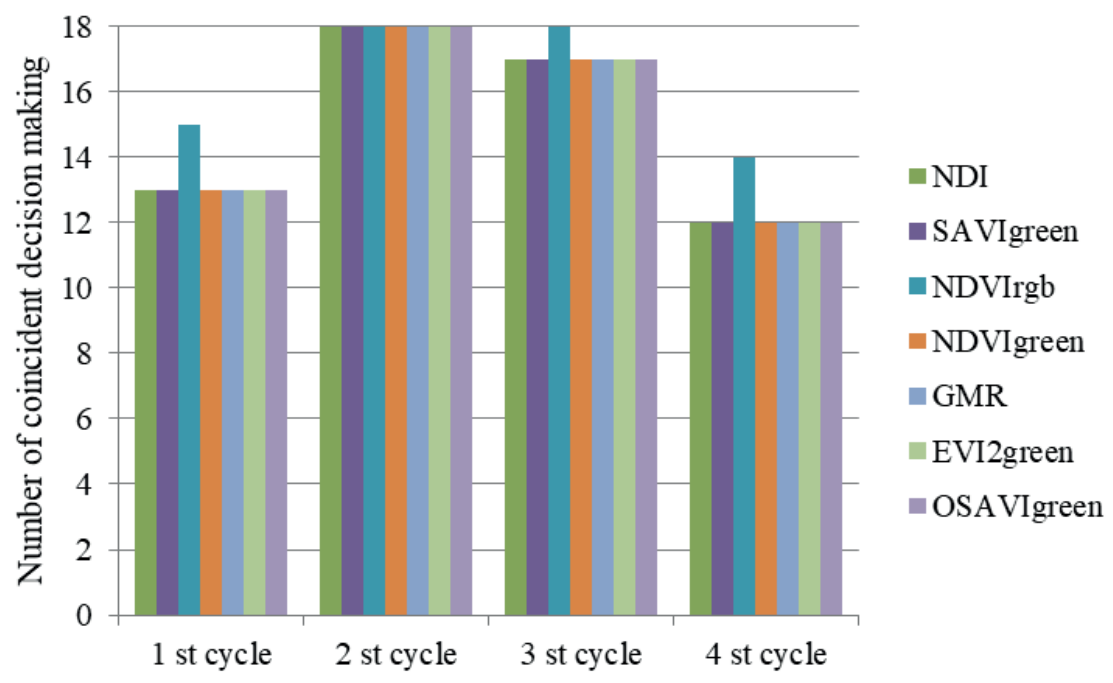


All indices were presented as potential alternatives in the use of conventional camera as a substitute for SPAD. However, the NDVI ${ }_{\mathrm{rgb}}$ index stands out. If this index was used as the input spectral variable in the NSI calculation, the decision based on this coincided more often than did the other VI evaluated.

This index is composed of three bands of the visible spectrum ( $R, G$ and $B$ ). Variation in the usual NDVI was based on the near infrared spectral band (NIR) and the R band (ROUSE et al., 1974). Leaf green intensity and $\mathrm{N}$ levels vary linearly with red band intensity (R) and the intensity of the green band $(\mathrm{G})$. However, it can indicate the levels of $\mathrm{N}$ indirectly via observed reflection of the photosynthetic pigments. This intensity tends to vary within each level of foliar N. However, the linearity between $\mathrm{G}$ intensity and $\mathrm{N}$ levels can possibly be improved by including the intensity of the blue band (B) (WIDJAJA PUTRA et al., 2017).

\section{Conclusion}

This work evaluated the response of pastures of the Xaraés variety to nitrogen fertilization based on nitrogen sufficiency index methodology (NSI). In addition to using the SPAD-502 chlorophyll meter for indirect quantification of leaf $\mathrm{N}$ level, the use of a digital camera was evaluated as a low-cost alternative. At the end of the study, it was possible to draw the following conclusions:

The efficiency of $\mathrm{N}$ use was higher for the NSI of 0.85 since the dry matter and foliar $\mathrm{N}$ yields were statistically the same as for other treatments that received nitrogen fertilization.

The treatments with $\mathrm{N}$ application at varied rates showed greater efficiencies in dry matter production than the treatment that received a single dose, resulting in $\mathrm{N}$ use economy.

The application of vegetation indices using bands in the visible region can be used as a fast method to determine the nutritional requirements of $\mathrm{N}$ in pastures of Brachiaria brizantha cv. Xaraés through the NSI.

Most indices studied presented a strong correlation with SPAD readings, but the NDVI $_{\text {rgb }}$ index was best adapted to the conditions of the study.

\section{Acknowledgments}

The authors thank the National Research Council (CNPq) and the Agricultural Research Company of Minas Gerais state (EPAMIG), for the financial resources and support for the implementation of the project.

\section{References}

BASSO, B.; CAMMARANO, D.; FIORENTINO, D.; RITCHIE, J. T. Wheat yield response to spatially variable nitrogen fertilizer in Mediterranean environment. European Journal of Agronomy, Montpellier, v. 51, p. 65-70, 2013. DOI: 10.1016/j.eja.2013.06.007.

BASSO, B.; DUMONT, B.; CAMMARANO, D.; PEZZUOLO, A.; MARINELLO, F.; SARTORI, L. Environmental and economic benefits of variable rate nitrogen fertilization in a nitrate vulnerable zone. Science of the Total Environment, Amsterdam, v. 545-546, n. 1, p. 227-235, 2016. DOI: 10.1016/j.scitotenv.2015.12.104

BERNARDI, A. C. C.; BETTIOL, G. M.; FERREIRA, R. P.; SANTOS, K. E. L.; RABELLO, L. M.; INAMASU, R. Y. Spatial variability of soil properties and yield of a grazed alfalfa pasture in Brazil. Precision Agriculture, Netherlands, v. 17, n. 6, p. 737-752, 2016. DOI: $10.1007 /$ s11119-016-9446-9

CAMARGO, A. C.; NOVO, A. L.; NOVAES, N. J.; ESTEVES, S. N.; MANZANO, A.; MACHADO, R. Produção de leite a pasto. In: SIMPÓSIO SOBRE O MANEJO DA PASTAGEM, 18., 2002, Piracicaba. Anais... Piracicaba: FEALQ, 2002. p. 285-319.

CARLOTO, M. N.; EUCLIDES, V.P. B.; MONTAGNER, D. B.; LEMPP, B.; DIFANTE, G. S.; PAULA, C. C. L. Desempenho animal e características de pasto de capimxaraés sob diferentes intensidades de pastejo, durante o período das águas. Pesquisa Agropecuária Brasileira, Brasília, v. 46, n. 1, p. 97-104, 2011. DOI: 10.1590/ S0100-204X2011000100013

CASTRO, L. M.; BARBOSA, M. A. A. F.; BARBERO, 
R. P.; BRITO, V. C.; SAAD, R. M.; RIBEIRO, E. L. A.; MIZUBUTI, I. Y.; BRIDI, A. M. Produção de forragem e composição estrutural de pastos de Brachiaria brizantha cv. Xaraés manejados em diferentes alturas de pastejo. Semina: Ciências Agrárias, Londrina, v. 34, n. 6, p. 4145-4156, 2013. DOI: 10.5433/1679-0359.2013v34n6Supl2p4145

COSTA, J. P. R.; CAPUTTI, G. P.; GALZERANO, L.; SILVA, W. L.; RUGGIERI, A. C.; MALHEIROS, E. B. Relative chlorophyll contents in the evaluation of the nutritional status of nitrogen from Xaraés palisade grass and determination of critical nitrogen sufficiency index. Acta Scientiarum. Animal Sciences, Maringá, v. 37, n. 2, p. 109-114, apr./june 2015. DOI: 10.4025/actascianimsci. v37i2.24854

DETMANN, E.; SOUZA, M. A.; VALADARES FILHO, S. C.; QUEIROZ, A. C.; BERCHIELLI, T. T.; SALIBA, E. O. S.; CABRAL, L. S.; PINA, D. S.; LADEIRA, M. M.; AZEVEDO, J. A. G. Métodos para análise de alimentos: INCT - Ciência Animal. Visconde do Rio Branco: Suprema, 2012. 214 p.

EUCLIDES, V. P. B.; MONTAGNER, D. B.; BARBOSA, R. A.; NANTES, N. N. Manejo do pastejo de cultivares de Brachiaria brizantha (Hochst) Stapf e de Panicum maximum Jacq. Revista Ceres, Viçosa, MG, v. 61, p. 808818 , nov./dez. 2014. Suplemento. DOI: 10.1590/0034$737 \times 201461000006$

FLORES, R. S.; EUCLIDES, V. P. B.; ABRÃO, M. P. C.; GALBEIRO, S.; DIFANTE, G. S.; BARBOSA, R. A. Desempenho animal, produção de forragem e características estruturais dos capins marandu e xaraés submetidos a intensidades de pastejo. Revista Brasileira de Zootecnia, Viçosa, MG, v. 37, n. 8, p. 1355-1365, 2008. DOI: $10.1590 / \mathrm{S} 1516-35982008000800004$

FONTES, J. G. G.; FAGUNDES, J. L.; BACKES, A. A.; BARBOSA, L. T.; CERQUEIRA, E. S. A.; SILVA, L. M. da; MORAIS, J. A. S.; VIEIRA, J. S. Herbage accumulation in Brachiaria brizantha cultivars submitted to defoliation intensities. Semina: Ciências Agrárias, Londrina, v. 35, n. 3, p. 1425-1438, maio/jun. 2014. DOI: $10.5433 / 1679-0359.2014 \mathrm{v} 35 \mathrm{n} 3 \mathrm{p} 1425$

FRANCIS, D. D.; PIEKIELEK, W. P. Assessing crop nitrogen needs with chlorophyll meters. SSMG. In: Site specific management guidelines. Potash and Phosphate Institute, Norcross, GA, 1999. Available at: http://www. ipni.net/ssmg. Accessed at: 18 mar. 2019.

GITELSON, A. A.; KAUFMAN, Y. J.; STARK, R.; RUNDQUIST, D. Novel algorithms for remote estimation of vegetation fraction. Remote Sensing of Environment, New York, v. 80, n. 1, p. 76-87, 2002. DOI: 10.1016/ S0034-4257(01)00289-9
GITELSON, A. A.; VIÑA, A.; CIGANDA, V.; RUNDQUIST, D. C.; ARKEBAUER, T. J. Remote estimation of canopy chlorophyll content in crops. Geophysical Research Letters, Washington, v. 32, L08403, p. 1-4, 2005. DOI: 10.1029/2005GL022688

GRACE, P. R.; ROBERTSON, G. P.; MILLAR, N.; COLUNGA-GARCIA, M.; BASSO, B.; GAGE, S. H.; HOBEN, J. The contribution of maize cropping in the Midwest USA to global warming: a regional estimate. Agricultural Systems, Essex, v. 104, n. 3, p. 292-296, 2011. DOI: 10.1016/j.agsy.2010.09.001

HE, L.; SONG, X.; FENG, W.; GUO, B. B.; ZHANG, Y. S.; WANG, Y. H.; WANG, C. Y.; GUO, T. C. Improved remote sensing of leaf nitrogen concentration in winter wheat using multi-angular hyperspectral data. Remote Sensing of Environment, New York, v. 174, n. 1, p. 122133, 2016. DOI: $10.1016 /$ j.rse.2015.12.007

HUNT JR., E. R.; DORAISWAMY, P. C.; MCMURTREY, J. E.; DAUGHTRY, C. S. T.; PERRY, E. M.; AKHMEDOV, B. A visible band index for remote sensing leaf chlorophyll content at the Canopy scale. International Journal of Applied Earth Observation and Geoinformation, Enschede, v. 21, n. 1, p. 103-112, 2013. DOI: $10.1016 /$ j.jag.2012.07.020

INSTITUTO BRASILEIRO DE GEOGRAFIA E ESTATÍSTICA - IBGE. Censo Agro 2017. Accessed at: https://censos.ibge.gov.br/agro/2017/templates/censo agro/resultadosagro/estabelecimentos.html. Accessed at: 31 jan. 2019.

JINWEN, L. Determination of canopy's average SPAD readings based on the analysis of digital images. Agrotechnology, Hyderabad, v. 3, n. 1, p. 1-4, 2014. DOI: 10.4172/2168-9881.100012

LI, F.; MISTELE, B.; HU, Y.; CHEN, X.; SCHMIDHALTER, U. Reflectance estimation of canopy nitrogen content in winter wheat using optimised hyperspectral spectral indices and partial least squares regression. European Journal of Agronomy, Montpellier, v. 52, part B, p. 198-209, 2014. DOI: $10.1016 / j$. eja.2013.09.006

LI, Y.; CHEN, D.; WALKER, C. N.; ANGUS, J. F. Estimating the nitrogen status of crops using a digital camera. Field Crops Research, Amsterdam, v. 118, n. 3, p. 221-227, 2010. DOI: 10.1016/j.fcr.2010.05.011

MAO, W.; WANG, Y. Real-time detection of betweenrow weeds using machine vision. American Society of Agricultural Engineers. St. Joseph: The Society for Agricultural, Food, and Biological Systems, 2003.

MATLAB version R2009b. Natick: The MathWorks Inc., Massachusetts, USA. 2009. 
MUTANGA, O.; SKIDMORE, A. K.; PRINS, H. H. T. Predicting in situ pasture quality in the Kruger National Park, South Africa, using continuum-removed absorption features. Remote Sensing of Environment, New York, v. 89, n. 3, p. 393-408, 2004. DOI: 10.1016/j. rse.2003.11.001

NETTO, A. T.; CAMPOSTRINI, E.; OLIVEIRA, J. G. de; BRESSAN-SMITH, R. E. Photosynthetic pigments, nitrogen, chlorophyll a fluorescence and SPAD-502 readings in coffee leaves. Scientia Horticulturae, Amsterdam, v. 104, n. 2, p. 199-209, 2005. DOI: 10.1016/j.scienta.2004.08.013

ORGANIZAÇÃO DAS NAÇÕES UNIDAS - ONU. Brasil na COP 21. 2015. Available at: http://www.mma. gov.br/clima/convencao-das-nacoes-unidas/acordo-deparis. Accessed at: 7 jan. 2017.

PAGOLA, M.; ORTIZ, R.; IRIGOYEN, I.; BUSTINCE, H.; BARRENECHEA, E.; APARICIO-TEJO, P.; LAMSFUS, C.; LASA, B. New method to assess barley nitrogen nutrition status based on image colour analysis: comparison with SPAD-502. Computers and Electronics in Agriculture, Amsterdam, v. 65, n. 2, p. 213-218, 2009. DOI: 10.1016/j.compag.2008.10.003

PEDREIRA, B. C. E.; PEDREIRA, C. G. S.; SILVA, S. C. da. Acúmulo de forragem durante a rebrotação de capim-xaraés submetido a três estratégias de desfolhação. Revista Brasileira de Zootecnia, Viçosa, MG, v. 38, n. 4, p. 618-625, 2009. DOI: 10.1590/S151635982009000400005

PEDREIRA, B. C.; PEDREIRA, C. G. S.; SILVA, S. C. da. Estrutura do dossel e acúmulo de forragem de Brachiaraia brizantha cultivar Xaraés em resposta a estratégias de pastejo. Pesquisa Agropecuária Brasileira, Brasília, v. 42, n. 2, p. 281-287, 2007. DOI: 10.1590/ S0100-204X2007000200018

PERALTA, N. R.; COSTA, J. L. Delineation of management zones with soil apparent electrical conductivity to improve nutrient management. Computers and Electronics in Agriculture, Amsterdam, v. 99, nov., p. 218-226, 2013. DOI: 10.1016/j.compag.2013.09.014

PEREIRA, R. C.; RIBEIRO, K. G.; PEREIRA, O. G.; VILLELA, S. D. J.; SILVA, J. de L. Produtividade, composição químico-bromatológica e extração de minerais das cultivares Marandu e Xaraés nas estações do ano. Veterinária e Zootecnia, Botucatu, v. 18, n. 1, p. 570-582, 2011.

R CORE TEAM - R: a language and environment for statistical computing. Vienna: $\mathrm{R}$ Foundation for Statistical Computing, 2016.
RIBEIRO, A. C.; GUIMARÃES, P. T. G.; ALVAREZ, V. H. V. Recommendations for the use of correctives and fertilizers in Minas Gerais. $5^{\text {th }}$ Approximation. Viçosa, MG: Soil Fertility Commission of the Minas Gerais State, 1999. 359 p.

ROBERTSON, M. J.; LLEWELLYN, R. S.; MANDEL, R.; LAWES, R.; BRAMLEY, R. G. V.; SWIFT, L.; METZ, N.; O'CALLAGHAN, C. Adoption of variable rate fertiliser application in the Australian grains industry: Status, issues and prospects. Precision Agriculture, Netherlands, v. 13, n. 2, p. 181-199, 2012. DOI: 10.1007/ s11119-011-9236-3

ROUSE, J. W.; HAAS, R. H.; SCHELL, J. A.; DEERING, D. W.; HARLAN, J. C. Monitoring the vernal advancement of retrogradation of natural vegetation. Greenbelt: NASA/GSFC, 1974. 371 p. (Final Report).

SABERIOON, M. M.; AMIN, M. S. M.; AIMRUN, W.; GHOLIZADEH, A.; ANUAR, A. A. R. Assessment of colour indices derived from conventional digital camera for determining nitrogen status in rice plants. Journal of Food, Agriculture and Environment, Helsinki, v. 11, n. 2, p. 655-662, 2013. DOI: 10.1234/4.2013.4391

SABERIOON, M. M.; AMIN, M. S. M.; ANUAR, A. R.; GHOLIZADEH, A.; WAYAYOK, A.; KHAIRUNNIZABEJO, S. Assessment of rice leaf chlorophyll content using visible bands at different growth stages at both the leaf and canopy scale. International Journal of Applied Earth Observation and Geoinformation, Enschede, v. 32, oct., p. 35-45, 2014. DOI: 10.1016/j.jag.2014.03.018

SAMBORSKI, S. M.; TREMBLAY, N.; FALLON, E. Strategies to make use of plant sensors-based diagnostic information for nitrogen recommendations. Agronomy Journal, Madison, v. 101, n. 4, p. 800-816, 2009. DOI: 10.2134/agronj2008.0162Rx

SILVA, J. A.; SILVA, C. G. M.; SOUSA, D. P.; PAULA, N. F. de; CARVALHO, A. P. S.; MACEDO, B. G.; COSTA JÚNIOR, W. S. da; BIANCHI-ZANETTE, I. E.; COSTA, R. V.; TEOBALDO, R. W. Supplementation strategies for dairy cows kept in tropical grass pastures. Semina: Ciências Agrárias, Londrina, v. 38, n. 1, p. 401-416, jan./ fev. 2017. DOI: 10.5433/1679-0359.2017v38n1p401

VALLE, C. B.; EUCLIDES, V. P. B.; PEREIRA, J. M.; VALÉRIO, J. R.; PAGLIARINI, M. S.; MACEDO, M. C. M.; LEITE, G. G.; LOURENÇO, A. J.; FERNANDES, C. D.; DIAS-FILHO, M. B.; LEMPP, B.; POTT, A.; SOUZA, M. A. de. O capim-Xaraés (Brachiaria brizantha cv. Xaraés) na diversificação das pastagens de braquiária. Campo Grande: EMBRAPA Gado de Corte, 2004. 36 p. 
VILLAR, F. M. M.; PINTO, F. A. C.; FONSECA, D. M.; QUEIROZ, D. M.; ALCÂNTARA, G. R. Sufficiency index for defining nitrogen recommendation in brachiaria grass pasture. Bioscience Journal, Uberlândia, v. 31 , n. 5 , p. $1333-1340$, 2015. DOI: 10.14393/BJv31n5a2015-26338

WANG, Y.; WANG, D.; SHI, P.; OMASA, K. Estimating rice chlorophyll content and leaf nitrogen concentration with a digital still color camera under natural light. Plant Methods, London, v. 10, n. 36, p. 1-11, 2014. DOI: 10.1186/1746-4811-10-36
WANG, Y.; WANG, D.; ZHANG, G.; WANG, J. Estimating nitrogen status of rice using the image segmentation of G-R thresholding method. Field Crops Research, Amsterdam, v. 149, n. 1, p. 33-39, 2013. DOI: 10.1016/j.fcr.2013.04.007

WIDJAJA PUTRA, B. T.; SONI, P. Enhanced broadband greenness in assessing chlorophyll $\mathrm{a}$ and $\mathrm{b}$, carotenoid, and nitrogen in robusta coffee plantations using a digital camera. Precision Agriculture, Netherlands, v. 19, n. 2, p. 1-19, 2017. DOI: 10.1007/s11119-017-9513-x 